\title{
ПИТАННЯ МОТИВАЦІЇ КАДРІВ ДОШКІЛЬНОЇ ОСВІТИ (ІСТОРИКО-ПЕДАГОГІЧНИЙ АСПЕКТ)
}

\section{Танько Т. П.}

доктор педагогічних наук, професор, декан факультету дошкільної освіти, Харківський національний педагогічний університет імені Г. С. Сковороди, м. Харків, Україна

У статті доведено, щзо мотиващія кадрів дошкільної освіти до професійного зростання в кіниі XIX - на початку XX століття була пов'язана з: активною діяльністю земств, приватних осіб та товариств; відкриттям спеціальних педагогічних курсів для дошкільних працівників; створенням широкої мережі ЗДО; проведенням з 'їдів; виданням спеціального журналу тощо.

Ключові слова: мотивачія, дошкільні прачівники, професійне зростання.

The article proves that the motivation of preschool staff for professional growth at the end of the 19th century - at the beginning of the 20th century was connected with certain factors, such as: active works of zemstvos, private individuals and societies; introduction of special pedagogical courses for preschool staff; creating a wide network of preschool educational institutions; holding of congresses; publication of a special journal etc.

Key words: motivation, preschool staff, professional growth.

Аналіз науково-педагогічних матеріалів дозволяє констатувати, що становлення системи мотивації кадрів дошкільної освіти до професійного зростання в Україні було пов'язане з прийняттям у першій половині XIX століття «Попередніх правил народної освіти», котрі передбачали створення навчальних округів, що сприяло розвитку дошкільної освіти в різних регіонах.

Варто також звернути увагу на те, що в 70-ті рр. XIX століття значну роль щодо розв' язання проблем мотивації кадрів дошкільної освіти відіграли земства, приватні особи і товариства. Так, у відповідності з Положенням про губернські й повітові земські установи, було передбачено, що земства повинні піклуватися про стан міських та сільських закладів освіти, зокрема дошкільної галузі.

Як свідчать науково-педагогічні джерела, заохочувальна діяльність земств відрізнялась різноплановістю. Саме земства надавали стипендії, оплачували за навчання, надавали грошову допомогу, допомагали ре- 
чами і продуктами, виділяли кошти на утримання закладів освіти, допомагали благодійним товариствам та ін.

У роки проведення великих реформ була створена система міського самоврядування, котра займалася питаннями задоволення соціальних запитів населення і заохоченням працівників дошкільної освіти до професійного зростання. Саме на місцеві інститути держава перекладала основні турботи щодо розвитку галузі освіти. Громадське управління надавало дошкільним працівникам житло, сприяло підвищенню їхньої кваліфікації, використовувало форми матеріального і морального заохочення. Саме міські думи опікувалися приватними заповітами, надавали пожертвування на добродійні цілі, утримували заклади дошкільної освіти і займалися реалізацією питань мотивації кадрів дошкільної освіти.

Так, органи міського самоврядування витрачали кошти на заробітну платню фахівцям дошкільного профілю, на оплату приміщень, на закупівлю підручників та навчальних посібників, на матеріальну допомогу сім'ям, облаштування бібліотек і народних читальнь. 3 метою мотивації кадрів дошкільного профілю до професійного зростання органи управління відкривали чоловічі і жіночі прогімназії та гімназії [1].

Як свідчать науково-педагогічні матеріали, матеріальні форми були одним із найвагоміших стимулів щодо мотивації кадрів дошкільного профілю.

У кінці XIX століття вагомим чинником мотивації дошкільних працівників було видання спеціальних педагогічних збірок для вихователів закладів дошкільної освіти, які включали розробку предметних бесід із дошкільниками на городі, садку, у полі, на річці та ін.

Суттєвою заслугою зазначеного періоду можна вважати і відкриття спеціальних педагогічних курсів для фахівців дошкільної освіти, створення широкої мережі дошкільних закладів, котрі повністю відповідали гігієнічним вимогам.

Велику роль щодо мотивації кадрів дошкільного профілю до професійного зростання відіграли педагогічні товариства, які були створені наприкінці XIX — першій половині XX століття, - Київське товариство народних дитячих садків і Фребелівське педагогічне товариство, котрі брали активну участь в організації першої Всеросійської виставки іграшок у Петербурзі. Саме педагогічні товариства на виставці представили вітрину з іграми, конспектами занять, роботами 
Розділ III. Історичні та порівняльні аспекти в теорії і практиці духовно-інтелектуального виховання й навчання

дітей дошкільного віку, зразками робіт учнів школи нянь, друкованими виданнями товариства, пояснювальними записками 3 відомостями щодо діяльності курсів, закладів дошкільної освіти товариства.

На Всесвітній педагогічній виставці у Парижі (1900 рік) була позитивно відзначена діяльність Фребелівського педагогічного товариства.

Необхідно звернути увагу на те, що наприкінці XIX - початку XX століття питання мотивації дошкільних працівників до самовдосконалення порушувалися на різноманітних з’їздах із питань народної освіти. Наприклад, на I та II з'їдах зазначені питання в своїх доповідях порушували А. Катаєва та К. Цируля. На ІІІ з’їзді (1904 р.) О. Клокова - голова Петербурзького Фребелівського товариства — виступила 3 доповіддю «Про дитячі садки», в якій зазначила про необхідність: поширення інформації про діяльність дитячих садків; забезпечення взаємозв'язку закладів дошкільної освіти з родиною; заснування безкоштовних народних дитячих садків.

Вагому роль щодо мотивації дошкільних працівників до самовдосконалення на початку XX століття відіграли запропоновані Товариством виставки «Дошкільне виховання» (1908 рік) та «Дитяча праця» (1910 рік) [2].

Визначаючи одним із провідних завдань поширення ідей мотивації кадрів дошкільного профілю, Київське товариство народних дитячих садків внесло пропозицію щодо заснування спеціального журналу 3 дошкільної освіти.

Починаючи з січня 1911 року Фребелівське товариство почало видавати журнал «Дошкільне виховання», котрий широко представляв інформацію про діяльність народних дитячих садків і заохочував до роботи в них [2].

У 1924 році була проведена Всеукраїнська нарада завідувачів відділами соціального виховання, яка радила взяти під контроль справу дошкільного виховання, розгорнути серед населення широку пропаганду стосовно створення нових закладів дошкільної освіти, що сприяло збільшенню кількості кадрів дошкільного профілю.

Суттєвий внесок у справу розвитку питань мотивації дошкільних працівників до професійного зростання мала і розробка та видання у 1932 році програми дитячого садка та прийняття цілої низки урядових постанов щодо виховання дітей дошкільного віку. Серед зазначених документів можна назвати Постанову (6 липня 1935 рік) «Про заходи 
щодо упорядкування роботи дитячих садів». У відповідності до зазначеної Постанови було встановлено 9-годинну тривалість робочого дня у дитячих садках.

Усе це сприяло тому, що в системі дошкільної освіти з'явилися ентузіасти-вихователі, котрі добре працювали з батьками й громадськістю, володіли високим рівнем педагогічної майстерності, постійно дбали про підвищення свого професійного рівня і брали активну участь у громадській роботі.

3 метою ефективної організації методичної роботи, пропаганди і широкого впровадження досвіду діяльності кращих дошкільних працівників, починаючи з 1932 року, при закладах дошкільної освіти почали працювати методичні кабінети. Вивчення й узагальнення передового педагогічного досвіду стало дієвим чинником подальшого розвитку форм мотивації кадрів дошкільної освіти до самовдосконалення.

Розвитку та вдосконаленню питань теорії та практики мотивації дошкільних працівників до професійного зростання сприяли Статут і програмно-методичні матеріали під загальною назвою «Керівництво для вихователя дитячого садка» (1938 рік). У відповідності до зазначених документів від завідувачки закладу дошкільної освіти і вихователів вимагалась спеціальна педагогічна освіта, що виступало своєрідною формою мотивації кадрів дошкільної освіти до професійного зростання, тому що в той час не кожен дошкільний працівник мав педагогічну освіту.

Доцільно також наголосити на тому, що в 50-ті pp. XX століття в Україні відбувалося велике колгоспне будівництво, котре вимагало створення в сільській місцевості широкої мережі закладів освіти, зокрема дитячих садків і дитячих майданчиків, і усе це потребувало професійної підготовки досвідчених вихователів.

Значна увага в цей період приділялась курсам із підготовки дошкільних працівників. 3 цією метою в Україні для організації курсів у кожному районі було створено спеціальну комісію із представників районної Ради депутатів трудящих, відділів народної освіти, охорони здоров'я, сільського господарства.

Зазначені комісії розробляли план підготовки керівників і вихователів закладів дошкільної освіти, визначали потребу в цих кадрах по кожному з районів області, а також затверджували склад слухачів курсів із підготовки дошкільних працівників. 
Отже, мотивації кадрів дошкільної освіти до професійного вдосконалення в кінці XIX - на початку XX століття сприяли: активна діяльність земств, органів місцевого самоврядування, приватних осіб і товариств; видання спеціальних педагогічних збірок для вихователів закладів дошкільної освіти; відкриття спеціальних педагогічних курсів для фахівців дошкільної освіти; створення широкої мережі дошкільних закладів; відкриття Київського товариства народних дитячих садків та Фребелівського педагогічного товариства; участь дошкільних працівників у Всесвітній педагогічній виставці у Парижі; порушення зазначених питань на різноманітних освітніх з'їздах; організація виставок «Дошкільне виховання» та «Дитяча праця»; видання спеціального журналу «Дошкільне виховання»; проведення Всеукраїнської наради завідувачів відділами соціального виховання; видання програми дитячого садка; прийняття низки урядових постанов щодо виховання дітей дошкільного віку; створення при ЗДО методичних кабінетів та ін.

\section{Список використаних джерел:}

1. Российская педагогическая энциклопедия Москва : Большая российская энциклопедия, 1993. $1376 \mathrm{c}$.

2. Ступак Ф. Я. Діяльність благодійних товариств Києва другої половини XIX — початку XX століття. : автореф. дис. ... канд. іст. наук : 07.00.01. Київ, 1997. 23 с. 